DOI dx.doi.org/10.24866/7444-4707-6/57-67

Б.Ф. Пиеничников, Н.Ф. Пиеничникова

\title{
МОРФОГЕНЕТИЧЕСКОЕ РАЗНООБРАЗИЕ И КЛАССИФИКАЦИЯ ПРИОКЕАНИЧЕСКИХ БУРОЗЕМОВ ЮГА ДАЛЬНЕГО ВОСТОКА РОССИИ
}

В последние десятилетия на фоне активной разработки классификации почв России [2004, 2008] произошли существенные изменения и в вопросах региональной классификации почв юга Дальнего Востока. Было установлено, что определяющим фактором формирования буроземов прибрежно-островной зоны Японского моря России является антропогенная трансформация хвойно-широколиственных лесов. Она сопровождается усилением геохимического воздействия Тихого океана на буроземы, сменой их щелочно-кислотного состояния и резким увеличением ионов магния в составе их обменных катионов [Пшеничников, Пшеничникова, 2002, 2005; Pshenichnikov et al., 2014]. Следствием этого является возрастание подвижности гумуса в профиле буроземов, активизация в них аккумулятивно-гумусового, а также развитие элювиально-гумусового и иллювиально-гумусового элементарных процессов почвообразования (ЭПП). Это предопределяет формирование большого морфологического разнообразия приокеанических буроземов, что в настоящее время не нашло отражение в современной классификации почв России.

Цель данного исследования - показать разнообразие строения почвенных профилей буроземов прибрежно-островной зоны и формирующие их ЭПП.

Почвенные исследования проводились на островах Русский, Попова, Рейнеке, Рикорда, Путятина, на побережье и островах бухты Табунная (Сидорова, Герасимова, Бычьй), на побережье бухты Спасения и островах ДВМБ3 (Стенина, Большой Пелис, Дурнова, Гильдебранта, Матвеева), на 
побережьях мыса Островной, бухты Кит, на побережье и островах Крейсер бухты Триозерье, на острове Петрова.

Результаты отражены в ряде публикаций [Пшеничников, Пшеничникова, 2002, 2004, 2005, 2009, 2013, 2015, 2017; Пшеничников и др., 2005, 2010; Пшеничников и др., 2012, 2018, 2018a, 2018б; Пшеничников и др., 2010а; Пшеничников и др., 2012a, 2012б, 2009а; Ганзей и др., 2018; Киселёва и др., 2016; Лящевская и др., 2013, 2017; Родникова и др., 2017; Pshenichnikov et al., 2013, 2014].

Исследования почвенного покрова проводились на основании сравнительно-географического метода, что позволило выявить специфику условий формирования и морфологического строения буроземов в зависимости от литологической основы, положения в рельефе, состояния растительности и геохимического влияния моря. Аналитическая обработка материала проводилась общепринятыми методами [Аринушкина, 1970; Воробьева, 1998].

Различное сочетание ЭПП обуславливает морфогенетическое разнообразие приокеанических буроземов и является основой их классификации на типовом и подтиповом уровнях. Среди буроземов рассматриваемой территории широко развиты на типовом уровне: «буроземы» и «буроземы темные» [Классификация...2004]. В составе типа «буроземы» на региональном уровне проявляются специфические черты почвообразования, обусловленные фациальными условиями. Наряду с широко развитыми буроземами типичными, оподзоленными (отбеленными), глееватыми (глеевато-отбеленными) [Иванов, 1983)] на побережье северо-востока Приморья распространены своеобразные буроземы, которые предложено выделять на уровне подтипа - коричнево-бурые иллювиально-гумусовые буроземы [Пшеничников, Пшеничникова, 2009]. В типе «буроземы темные» - под разреженными травянистыми дубняками представлены буроземы темные типичные, а на безлесных территориях под травяно-кустарниковыми группировками - и буроземы темные иллювиально-гумусовые [Пшеничников, Пшеничникова, 2009].

Буроземы типичные формируются под широколиственными, хвойношироколиственными лесами. Для типичных буроземов характерна бурая, желто-бурая окраска средней части профиля - горизонт ВМ. Присутствие в нижней части подстилки, а в отдельных разрезах - в верхней части аккумуля- 
тивно-гумусового горизонта обгоревших фрагментов растительных остатков свидетельствует о пирогенезе этих почв и раскрывает причину малой мощности горизонта AY. Их профиль (O-AY-BM-С) является производным сочетания таких ЭПП как гумусонакопление и внутрипочвенное оглинивание (рис. 1). Для них характерен гуматно-фульватный состав гумуса (Сгк:Сфк = 0,7-0,8) и аккумулятивный характер его профильной дифференциации.

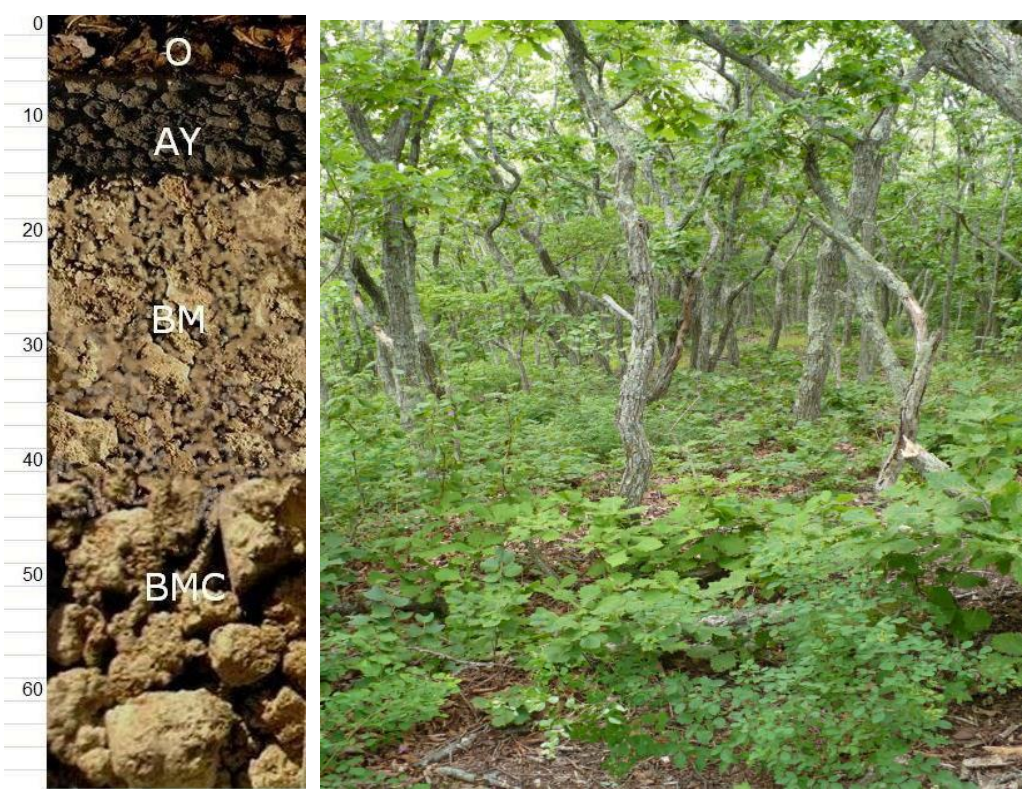

Puc. 1. Буроземы типичные (Острова и побережье залива Петра Великого)

Буроземы коричнево-бурые иллювиально-гумусовые формируются под изреженными, преимущественно, дубовыми лесами. Визуальными признаками иллювиирования гумуса в буроземах этой группы являются присутствие в гор. BMf,hi коричнево-бурых органо-минеральные кутан на поверхности структурных отдельностей и бурая окраска почвенной массы внутренней части, а также языковатый характер перехода от аккумулятивно-гумусового к иллювиально-гумусовому горизонту (рис. 2).

Для них, также как и для типичных буроземов, характерен гуматнофульватный состав гумуса (Сгк:Сфк $=0,7-0,8)$, однако гумус в них отличается значительно большей подвижностью в верхней части профиля и активным иллювиированием фульвокислот, особенно их агрессивной фракции, в средней части профиля. Максимальное осаждение агрессивной фракции ФК_1а в иллювиально-гумусовых горизонтах совпадает с максимумом содержания оксалаторастворимых оксидов железа, что в определенной степени и обеспечивает их коричнево-бурую окраску. 
Это обуславливает наложение на аккумулятивно-гумусовый процесс элювиально-гумусового, а на процесс внутрипочвенного оглинивания иллювиально-гумусового ЭПП и, как следствие, своеобразие профиля этих буроземов (O-AY-BMf,hi-C).

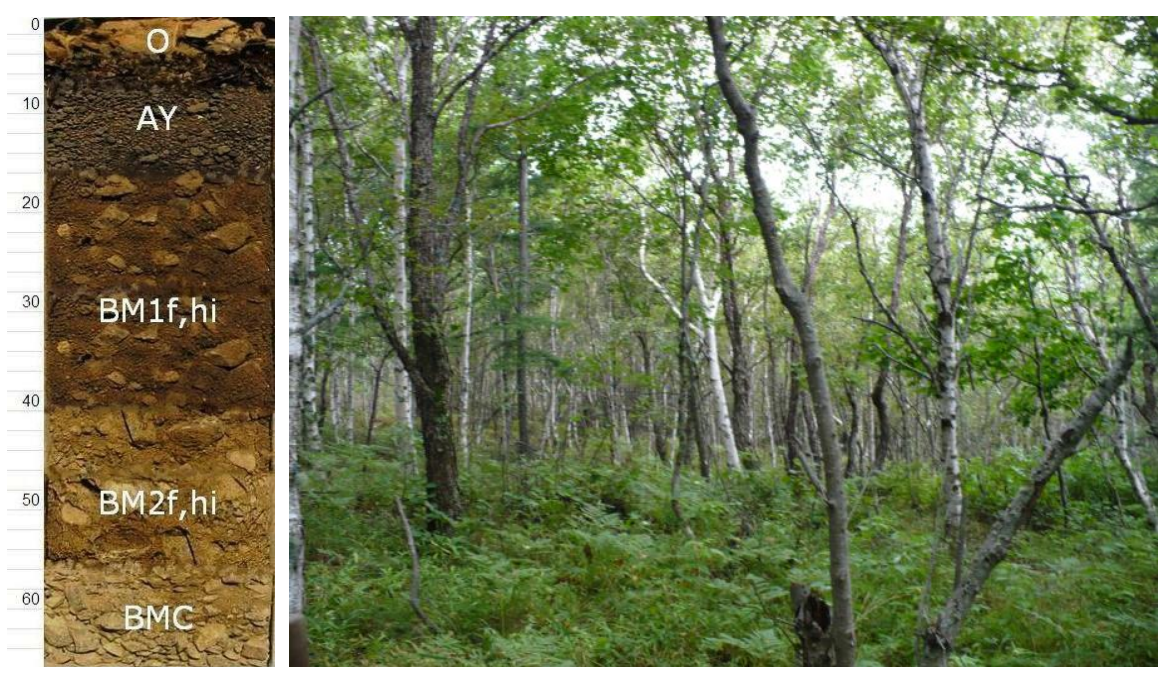

Puc. 2. Буроземы коричнево-бурые иллювиально-гумусовые (Лазовский район)

Буроземы темные типичные формируются под изреженными травянисто-кустарниковыми дубовыми лесами. Для профиля этих буроземов (O-AU-BM-C) характерно сочетание темногумусового и структурнометаморфического горизонтов. Их морфогенетические показатели во многом определяются фульватно-гуматным составом гумуса (Сгк:Сфк = 1,1-1,2) и аккумулятивным типом его внутрипрофильного распределения (рис.3).

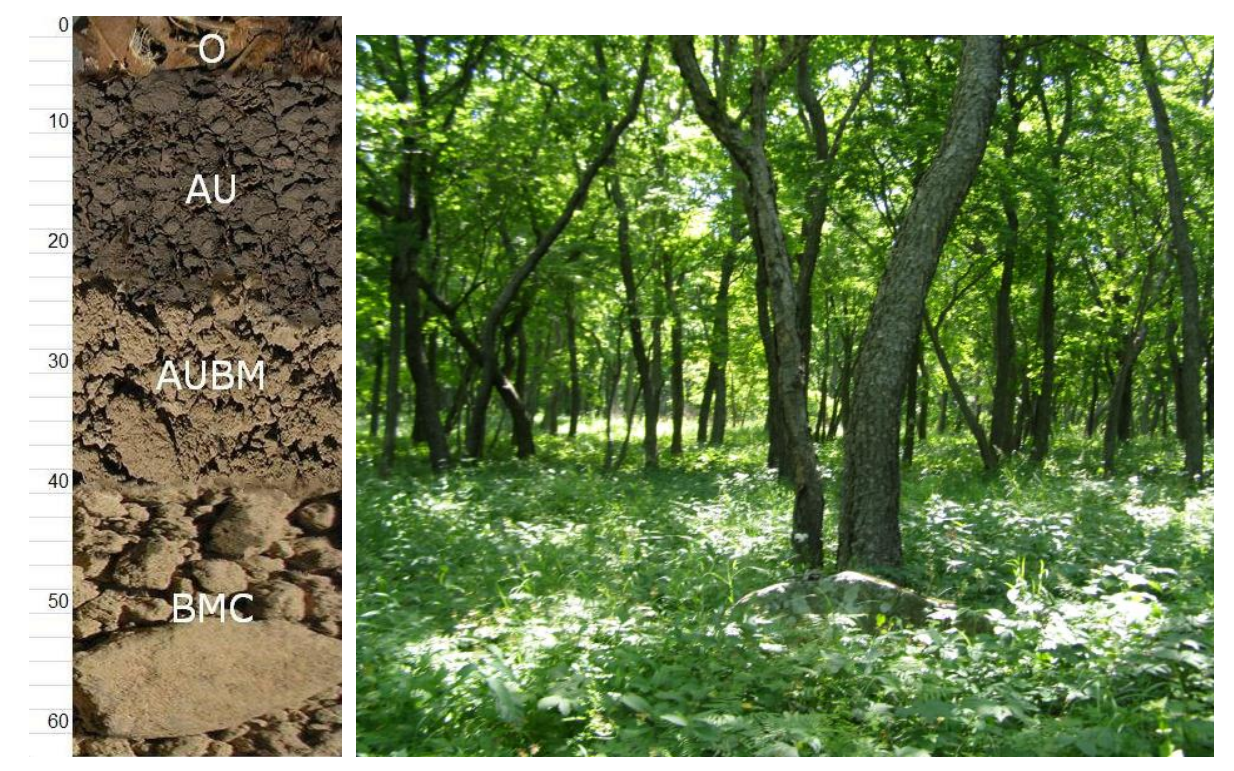

Puc. 3. Буроземы темные типичные (Острова залива Петра Великого) 
Буроземы темные иллювиально-гумусовые формируются под остепненными травяно-кустарниковыми группировками. Они выделяются большей потечностью гумуса и большим содержанием гуминовых кислот (Сгк:Сфк = 1,2-1,7). Это предопределяет формирование в профиле данных буроземов (O-AU-BMhi-C) мощного (до 40 , а иногда и 50 см) структурнометаморфически-иллювиально-гумусового горизонта темно-серого, серого цвета с высоким содержанием гумуса (4-8\%) и в его составе - фракций ЧГК и их производных с фульвокислотами (рис. 4).

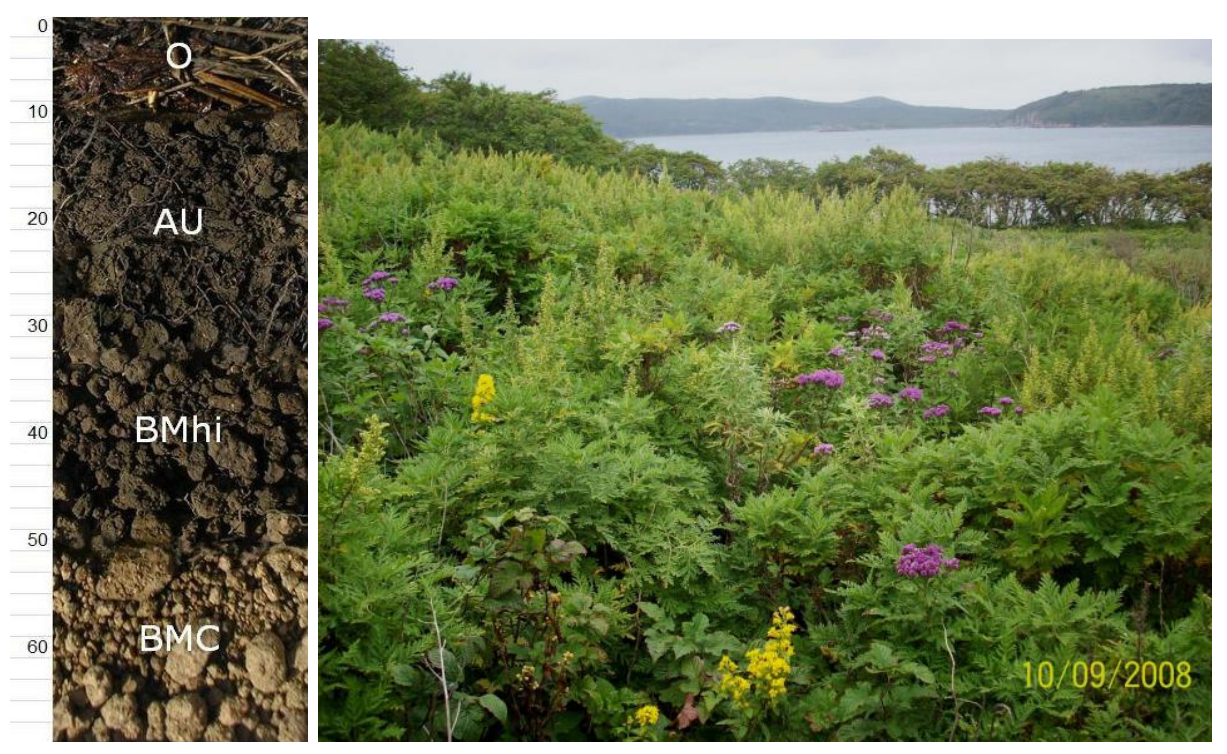

Puc. 4. Буроземы темные иллювиально-гумусовые (Острова залива Петра Великого)

Полигенетичные буроземы. Результаты наших исследований свидетельствуют о том, что реликтовые процессы почвообразования, с одной стороны, могут обусловливать формирование буроземов с простым полигенетичным профилем, а с другой - предопределять развитие буроземов со сложным полигенетичным профилем (рис. 5).

В профиле сложных полигенетичных буроземов согласно Т.В. Турсиной [2012], присутствуют погребенные гумусовые горизонты, унаследованные от былых стадий почвообразования, тогда как в профиле простых полигенетичных почв, отмечаются признаки литогенные унаследованные от реликтовых материнских пород, и современные педогенные.

Морфологическое строение сложных полигенетичных почвенных профилей, состав их спорово-пыльцевых спектров и данные о возрасте погребенных горизонтов [AY] свидетельствуют о том, что в основе формирования сложных полигенетичных буроземов п-ова Муравьёв-Амурского 
лежит пространственно-временная динамика факторов почвообразования [Пшеничников и др., 2012a, 2018б].
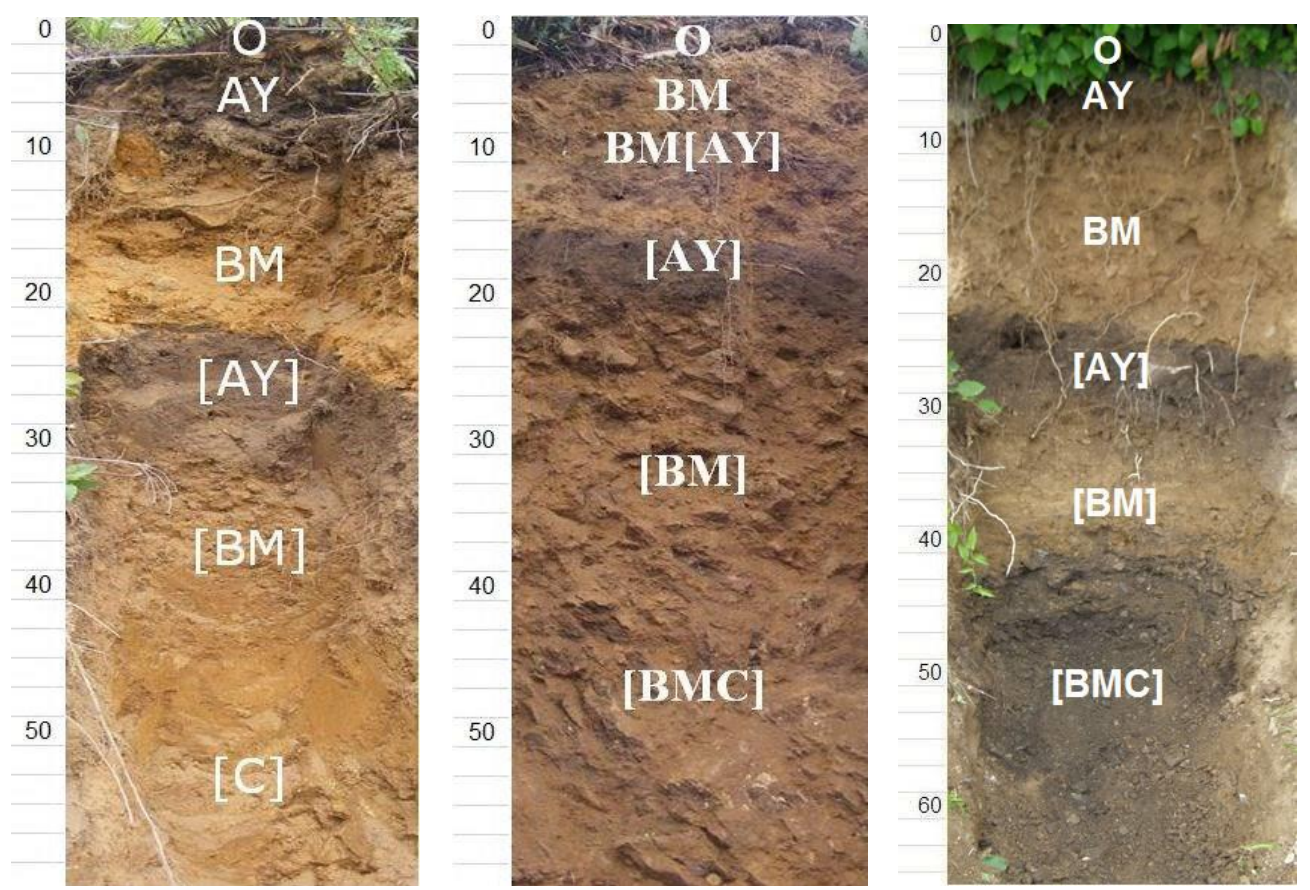

Puc. 5. Сложные полигенетичные буроземы (п-в Муравьев-Амурский, о-в Путянин)

Простые полигенетичные буроземы плиоценовых террас формируются на реликтовых красноцветных корах выветривания раннего голоцена [Пшеничников, Пшеничникова, 2017; Пшеничников и др., и др., 2009а, 2010а] (рис. 6).

Наши исследования показали правомерность выделения Г.И. Ивановым буроземов на крайнем юге российского Дальнего Востока, которые по морфологии и свойствам имеют значительное сходство с желтоземами, и определены им как «желто-бурые почвы» [Иванов, 1983]. Они формируются под редколесьями и разнотравно-злаковыми лугами, имеют гумусовый горизонт 8-12 см, резко переходящий в минеральный горизонт яркого желтовато-бурого цвета. Высказывались предположения, что эти почвы полигенетичны и их свойства во многом определяются реликтовыми желтоцветными корами выветривания, на которых они формируются.

Нами получены данные профильной динамики спорово-пыльцевых комплексов и реконструкции палеорастительности и климатических условий формирования каждого генетического горизонта рассматриваемых буроземов. Они подтвердили правомерность предположений о природе своеобразия морфологического строения, свойств, генезиса, а также клас- 
сификационного положения буроземов юга Дальнего Востока России [Пшеничников и др., 2018а, 2018б].
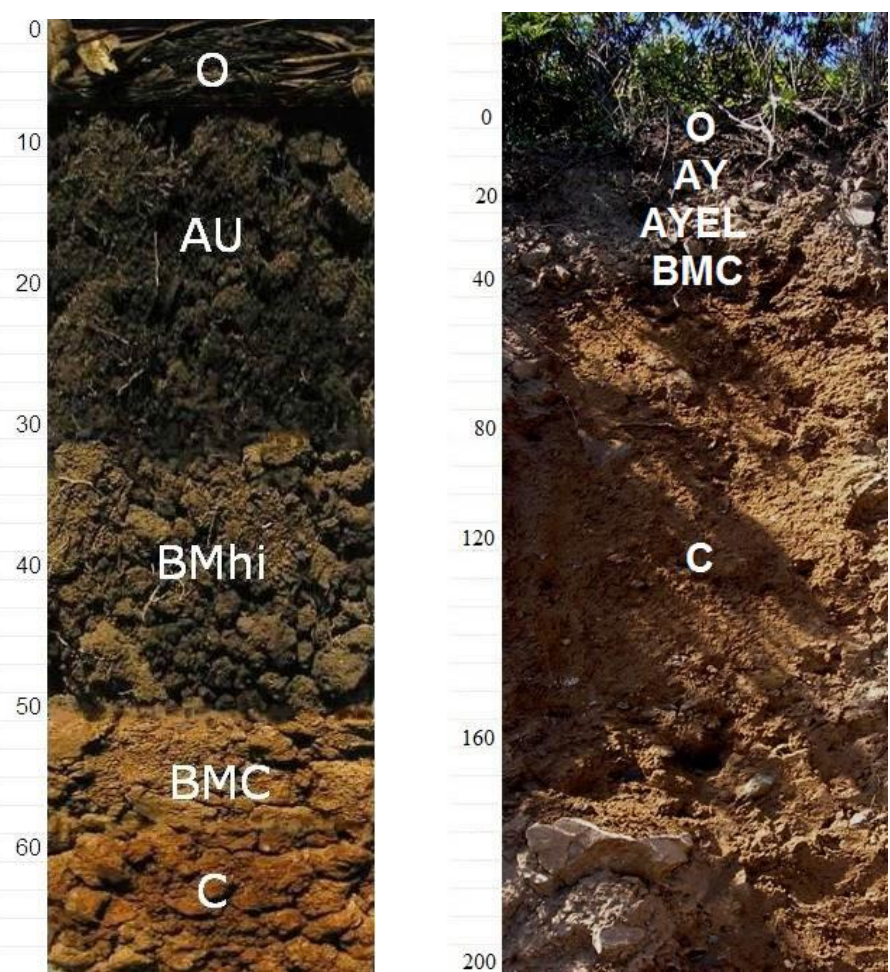

Puc. 6. Простые полигенетичные буроземы

(побережье бухты Спасения, острова ДВБМЗ; о-в Рикорда)
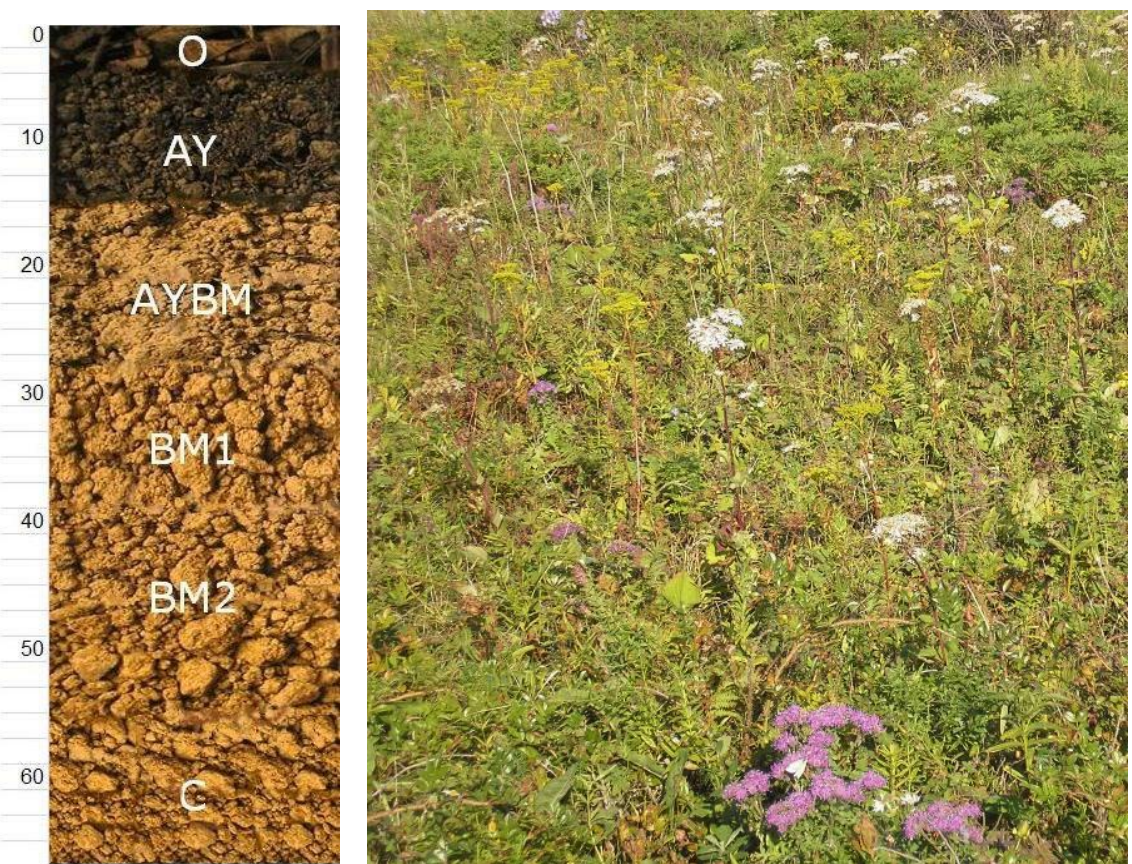

Puc. 7. Желто-бурые буроземы (п-в Муравьев-Амурский) 
Фациальность природных условий почвообразования на юге Дальнего Востока России при нарастающей антропогенной трансформации растительности предопределяет формирование большого морфологического разнообразия приокеанических буроземов. Результаты полевых и аналитических исследований свидетельствуют о ведущей роли состава гумуса и подвижности его отдельных фракций в развитии аккумулятивно-гумусового, элювиально-гумусового, иллювиально-гумусового элементарных процессов почвообразования и об их участии в формировании профиля.

\section{Литература}

1. Аринушкина Е.В. Руководство по химическому анализу почв. М.: Изд-во МГУ, 1970. - 490 с.

2. Воробьева Л.А. Химический анализ почв. Учебник. - М.: Изд-во МГУ, 1998. - 272 с.

3. Ганзей К.С., Киселёва А.Г., Родникова И.М., Лящевская М.С., Пшеничникова Н.Ф. Природные и антропогенные факторы развития геосистем острова Попова (Японское море) // География и природные ресурсы, 2018. №1. - С. 131-141.

4. Иванов Г.И. Почвенная карта Приморского края. М 1:500 000, 1983. ГУГК №2. - 9листов.

5. Киселева А.Г., Родникова И.М., Пшеничникова Н.Ф. Специфика почвенно-растительного покрова островов Скалы Крейсер (юго-восток Приморского края) // Международный журнал прикладных и фундаментальных исследований, 2016. № 1 - С. 183-186.

6. Классификации и диагностика почв России / Авторы и составители: Л.Л. Шишов, В..Д. Тонконогов, И.И. Лебедева, М.И. Герасимова. Смоленск: Щйкумена, 2004. - 343 с.

7. Лящевская М.С., Киселева А.Г., Родникова И.М., Пшеничникова Н.Ф. Почвенно-растительный покров материкового побережья бухты Табунной и близлежащих островов залива Петра Великого / География и природные ресурсы, 2013. № 3. - С. 91-99.

8. Лящевская М.С., Пшеничникова Н.Ф., Макарова Т.Р. Реакция растительности на климатические изменения в среднем-позднем голоцене (на примере участка побережья юго-восточного Приморья // Успехи современного естествознания, 2017. № 12. - С. 184-194. 
9. Полевой определитель почв. - М.: Почвенный ин-т им. В.В. Докучаева, 2008. - 182 с.

10. Пшеничников Б.Ф., Пшеничникова Н.Ф. Генезис и эволюция приокеанических буроземов (на примере япономорского побережья). Владивосток : Изд-во Дальневост. ун-та, 2002. - 292 с.

11. Пшеничников Б.Ф., Пшеничникова Н.Ф. Почвы островов и побережья // Дальневосточный морской биосферный заповедник. Исследования. Том 1. Глава IV «Почвы и ландшафты». Владивосток: Дальнаука, 2004. - С. 251-283.

12. Пшеничников Б.Ф., Пшеничникова Н.Ф. Геохимическое воздействие Тихого океана на почвы юга Дальнего Востока // Почвоведение : история, социология, методология. - М. : Наука, 2005. - С. 291-295.

13. Пшеничников Б.Ф., Пшеничникова Н.Ф. Генезис и классификация приокеанических буроземов Дальнего Востока // Продуктивность и устойчивость лесных почв : Материалы III междунар. конф. по лесному почвоведению. - Петрозаводск, 2009. - С. 94-97.

14. Пшеничников Б.Ф., Пшеничникова Н.Ф. Специфика формирования буроземов на островах залива Петра Великого (юг Дальнего Востока) // Вестник ДВО РАН, 2013. № 5. - С. 87-96.

15. Пшеничников Б.Ф., Пшеничникова Н.Ф. Влияние растительности на гумусообразование и морфологическое строение приокеанических буроземов юго-восточной части Приморья // Почвоведение, 2015. № 4. C. 387-396.

16. Пшеничников Б.Ф., Пшеничникова Н.Ф. Специфика формирования буроземов побережья острова Рикорда (залив Петра Великого, Приморский край) // Успехи современного естествознания. - 2017. № 8. - С. 106-110.

17. Пшеничников Б.Ф., Пшеничникова Н.Ф., Латышева Л.А.. Антропогенная динамика морфологического строения и лесорастительных свойств буроземов острова Русский // Вестник КрасГАУ, 2010 вып. 4. - С. 24-28.

18. Пшеничников Б.Ф., Пшеничникова Н.Ф., Латышева Л.А. Брюниземоподобные почвы острова Рейнеке // Вестник Томского госуниверситета. Приложение № 15. Материалы III Всероссийской научной конференции «Современные проблемы почвоведения и оценка земель Сибири». 2005. - С. 61-62.

19. Пшеничников Б.Ф., Лящевская М.С., Пшеничникова Н.Ф. Использование палинологических данных в диагностике и вопросах эволю- 
ции почв острова Петрова (Японское море) / География и природные ресурсы, 2012. № 2. - С. 146-154.

20. Пшеничников Б.Ф., Лящевская М.С., Пшеничникова Н.Ф. Специфика формирования буроземов острова Петрова (Лазовский заповедник, Приморский край) // Биота и среда заповедных территорий, 2018. № 3. - С. 5-20.

21. Пшеничников Б.Ф., Лящевская М.С., Пшеничникова Н.Ф. Полигенетичгые буроземы как отражение пространственно-временной динамики ландшафтов прибрежно-островной зоны залива Петра Великого (Японское море, Россия) / Материалы Международной науч. конф. «Третьи ландшафтно-экологические чтения, посвященные 100-летию со дня рождения Г.Е. Гришанкова». Симферополь, ИТ «АРИАЛ». 2018а. - С. 57-59.

22. Пшеничников Б.Ф., Лящевская М.С., Пшеничникова Н.Ф., Зубахо Е.Г. Проявление полигенетичности в буроземах прибрежно-островной зоны юга Приморья // География и природные ресурсы, 2018б. №2. C. 120-128.

23. Пшеничников Б.Ф., Милановский Е.Ю., Пшеничникова Н.Ф. Полигенетичные буроземы юга дальнего Востока // Материалы конференции «Биосферные функции почвенного покрова» 8-12 ноября. Пушино: SYNCHROBOOK, 2010a. - C. 255-257.

24. Пшеничников Б.Ф., Пшеничникова Н.Ф., Лящевская М.С., Зубахо Е.Г., Ханапин Е.В. Полигенетичные буроземы полуострова МуравьевАмурский: строение, свойства, генезис / Вестник ДВО РАН, 2012а. № 2 (162). - С. 25-34.

25. Пшеничников Б.Ф., Тюрин А.Н., Пшеничникова Н.Ф. Дальневосточный морской биосферный заповедник / Почвы заповедников и национальных парков Российской Федерации (гл. ред. Г.В. Добровольский, отв. ред. О.В. Чернова, В.В. Снакин, Е.В. Достовалова, А.А. Присяжная). М.: Фонд «Инфосфера» - НИА-Природа, 2012б. - С. 288-291

26. Пшеничников Б.Ф., Шеин Е.В., Милановский Е.Ю., Пшеничникова Н.Ф. Особенности формирования и эволюции буроземов приокеанической части юга_Дальнего Востока // Материалы V национальной конференции с международным участием «Эволюция почвенного покрова: история идей и методы, голоценовая эволюция, прогнозы». М., 2009а. - С. 209-211.

27. Родникова И.М., Лящевская М.С., Киселева А.Г., Пшеничникова Н.Ф. Состояние и динамика почвенно-растительного покрова малых ост- 
ровов залива Петра Великого (Японское море) / География и природные ресурсы, 2012. № 1. - С. 96-103.

28. Турсина Т. В. Подходы к изучению литологической однородности профиля и полигенетичности почв // Почвоведение, 2012. № 5. C. 530-546.

29. B.F. Pshenichnikov, N.F. Pshenichnikova M.S. Lyashchevskaya, E.G. Zubakho, E.V. Khanapin. Genesis of Polygenetic Burozems of MuravyovAmursky Peninsula as Reflection of Climate Dynamics and Increasing Anthropogenic Pressure / Pacific Science Review, 2013. T.15. № 3. - C. 165-174.

30. Pshenichnikov B.F., Pshenichnikova N.F. Classification of Maritime Burozems of The Southern Far East of Russia. Proceedings of the 20th WCSS (www.20wcss.org), Abstract Online Access System, June 8 to 13, 2014 Jeju, Korea. 